Marquette University

e-Publications@Marquette

History Faculty Research and Publications

History, Department of

2-1-1989

A Term Paper Project in Large Survey Courses

John Donnelly

Marquette University, john.p.donnelly@marquette.edu

Published version. The History Teacher, Vol. 22, No. 2 (February 1989): 117-124. DOI. (C) 1989

Society for History Education. Used with permission. 


\section{A Term Paper Project in Large Survey Courses}

John Patrick Donnelly, S.J.

Marquette University

THE OBJECTIVE OF INTRODUCTORY COURSES in history ought not be merely disseminating facts or even deepening insights into our collective past but also teaching tools of the liberal arts-research, analysis, organization, and skill at communicating ideas in clear, correct and forceful writing. These skills are fundamental not only to success in upper division courses but in the later careers of most college graduates. For many years I have been disheartened by the poor quality of many term papers written in my upper division courses, and I suspect that professors of history at most American colleges or universities have had the same experience. Some students do not know or use the mechanics of proper format, even though they may have been taught these in freshman writing courses. Many students spend too much time and effort finding and narrowing a topic that they can handle in a paper of ten to twenty pages. More serious, many students cannot write well. One reason forbad writing is lack of practice; another is the gap between freshmen English courses which teach writing and upper division humanities courses which regularly require term papers. A remedy for both is to require term papers in introductory courses so that freshmen put what they have been learning in their writing courses into immediate practice and therefore do not compartmentalize correct writing as something that applies only to freshman English. 
Requiring a research term paper presents special problems in very large introductory history courses. For the last ten years my classes in the survey of Western Civilization have averaged more than 1000 students, mostly freshmen, per semester. The logistics of more than 1000 term papers deterred me from requiring a paper. Correcting that many term papers was not a personal problem since I usually have the help of fourteen teaching assistants (TAs). ${ }^{1}$ For years I searched for a term paper project that could be used effectively in my courses. During the last two years I think I have found a solution. This essay tries to describe that solution and suggest how it might be applied to other large history classes.

A paper for a large introductory course should meet five criteria:

1. It should be fairly uniform as a requirement.

2. Its subject should be easy to define.

3. It should be fairly easy to research.

4. Students should have freedom in choosing their subject.

5. Each student should have a different subject.

These five criteria can be met by asking students to write a biographical sketch of a person whose life has contributed to the development of Western Civilization or American history, or whose life reflects the developments of an era. There are countless such persons. A single set of directions on how to research and write a biographical sketch can be given to students. The subject of a biographical sketch is automatically defined and structured by the individual person's life. Research is fairly easy because a person's name can be looked up in card catalogues, encyclopedias and indices. Students can select from a wide choice of persons that they find interesting; their choices seem to depend on the gender, nationality and area of achievement of the subject. For example, students interested in science can choose scientists; those interested in music can choose composers or musicians; those interested in politics can choose political or military figures, and so on. Finally, each student should have a different subject; otherwise a handful of eager students can strip the library of books that other students need. An added advantage of each student doing a different subject is that all students have to do their own work and that copying, no small problem in very large courses, is practically eliminated.

When I began this biographical sketch project I thought it enough to take a previous list such as Webster's Biographical Dictionary and check the entries which were important and appropriate to the subject matter of the course. A research assistant would then compile a list of those men and women which would include the person's name, dates, nationality, and occupation, e.g., general, scientist, writer, painter. I soon realized that such an a priori approach, although easy, would not work; many important 
people have not been the subject of biographies or such biographies are not in our library. Such subjects would then be difficult for freshmen to research, and I did not want to deluge the interlibrary loan desk with hundreds of requests. I therefore had to approach the problem a posteriori, by arranging for a research assistant to start at the beginning of the University Library's subject catalogue and prepare a card on every person relative to the second half of the Western Civilization course for whom our library had at least one biography in English. Each card had the following information: name, dates, gender (if not obvious from the name), nationality, area of contribution and an indication of the extent of our library's holdings on the person (e.g., ten books, including four biographies in English and one in German). If the holdings on the subject were thin, say only two books, then the full bibliographical data on these was recorded.

This was a big job. We accumulated nearly 2000 cards on subjects for the second half of Western Civilization for whom our library had at least one biography in English. I went through the 2000 cards and discarded about 300 subjects because the persons seemed too obscure or the library holdings too thin to make a good subject for a paper. I compiled a list of the remaining 1700 which included all the information from the cards except the library holdings. That was pretty close to the minimum needed for a course enrolling approximately 1100 students since the system should be elastic and some subjects on our list turned out to be "duds" after more research.

At the first discussion class of the semester, students received a sixpage set of directions for their papers. The first section of the directions discussed the purposes of term papers in general and of biographical sketches in particular and explained Barbara Tuchman's idea of how biography can function as a "prism of history" by showing the ways social, economic, political, religious, cultural and technological forces affect individual lives. ${ }^{2}$ The second section told how students could choose a congenial subject and suggested that the best subjects were neither the obscure nor the very famous. In one case finding material would be difficult, and in the other the sheer bulk of previous research might prove overwhelming. A third section spelled out the requirements and mechanics of the paper - contents, length, and the date papers were due. Students were expected to turn in an outline of their paper and bibliographical essay a month before the full paper to prevent procrastination and papers that were thrown together at the last minute. The final two sections made suggestions on how to research and organize the papers. Students were also given a pamphlet with directions about footnoting and other mechanics, but the handbooks used in most freshmen writing courses furnish similar material. 
During the first discussion class TAs circulated a section of the alphabetical list of subjects. Each TA had roughly ten pages with twelve subject entries each (e.g., Renan, Ernest [1823-1892] French philologist and historian) from which his or her seventy students were to choose their subjects. Since the list was alphabetical, it represented a cross section of subjects from various periods, countries, and areas of accomplishment. During this first discussion section students were asked to select five or six persons that seemed interesting and do some pre-research on them during the coming week; therefore, they could find out which subjects were really interesting and how much material our library had on them. At the second meeting of the discussion sections students "married" or signed up for a specific subject. Once a subject was selected, no other student could marry that subject. TAs kept back a few pages of entries for their later classes so that the early classes did not have an unfair advantage. Getting married to a congenial subject proved crucial for the satisfaction that students derived from the assignment. Inevitably, a fair number of students, perhaps ten percent, got into unhappy marriages. About half of these discussed their problem with theirTA, obtained a divorce, and selected a new subject from those remaining after the first two weeks of class.

During the first year of this project, students turned in their papers two weeks before their last discussion section. The second year the date for turning in papers was moved forward a week to give TAs more time for correcting and returning papers and for dealing with students who were delinquent in getting their papers in on time. Late papers were penalized. Failure to turn in a paper at all meant an Incomplete for the course; hence students had to write the paper to get credit for the course.

The term paper constituted thirty percent of the grade for the entire course. Grades were based equally on four criteria: 1. correctness (spelling, punctuation and grammar); 2. rhetoric (clarity, force, organization and students' success in making their subject come alive); 3. research (success in finding, evaluating, and incorporating material); and 4. skill in presenting the subject as a "prism of history," that is, in illustrating how the larger forces of history shaped or were shaped by the subject's life.

Since the term project grew out of my contacts with the Writing Across the Curriculum program and was largely graded on grammatical and rhetorical skills taught in freshman English courses, my TAs and I worked closely with the English Department. Roughly half of the students taking freshmen English were writing a paper for my course, so teachers in the English Department could tie some of their teaching to the history project. The History TAs read literature explaining the Writing Across the Curriculum program and received copies of the handbook used in the English Department for freshman writing courses so that they could make refer- 
ence to that work in their comments and corrections on student papers. In preparing the History TAs for the term paper project, we held a short, joint workshop with several professors and TAs from the English Department. The History TAs got a better idea of how they could help our students develop writing skills. The English TAs learned the details of our project and discussed writing and organizational problems experienced by freshmen. Later we encouraged our students to take drafts of their papers to the University's Writing Center, which is operated by the English Department and provides students with one-on-one help in improving their writing skills. Since most of our students must take courses in foreign languages, we also tried to link their papers to what they were learning in the Language Department by awarding a small bonus to students who made effective use of source material in foreign languages. It seldom crosses the mind of undergraduates that they can and should use their language skills in their other courses. About ten percent of our students seem to have chosen their subject with an eye to earning the bonus.

We asked students to include a bibliographical essay as the last page of their papers. We made photocopies of these pages after the first year of the project; the second year we arranged them alphabetically and distributed them to those TAs whose students were working on a parallel part of the alphabetical list of subjects this year. By comparing the bibliographical essays of the two years, we had a quick way of comparing the research effort of this year's students with those who had worked on the same subject the previous year.

Since I always take one discussion section myself, I shared the TAs' task of helping students prepare their papers and the chore of correcting them. Because each student was working on a different subject, I found correcting papers less tedious than usual and learned a good deal from them. This has not often been my experience in the past. My TAs also appreciated the variety.

At the end of both years of the project a cross-section of students were asked to fill out a questionnaire seeking their reaction to the assignment. Only the results from the second year were tabulated statistically. The questionnaire had twelve questions with multiple choice answers plus an invitation for students to discuss ways to improve the assignment. Several questions dealt with the directions given students and the sources they had used. The most fundamental question came last: "Did you find this an interesting and worthwhile assignment?" The response was 49 percent yes, 43 percent maybe, and 8 percent no. Since the project involved writing a term paper not previously required, the student response was distinctly favorable. Nearly 62 percent of the students felt that they had chosen an interesting and rewarding person to work on, while 15 percent felt that 
their subject, although somebody that they wanted to work on, turned out a dud; 8 percent said they could not get any subject that interested them, and 15 percent admitted that they had taken a shot in the dark when picking their subject. Most students (61 percent) based their choice on the subject's area of achievement (e.g., politics, music, science). Other students chose subjects on the basis of nationality (15 percent) or gender ( 7 percent); some students chose their subjects at random (8 percent) or on how easy they seemed to research ( 9 percent). The hardest part of the assignment for 43 percent of students was trying to present their subject as a prism of history; 32 percent had the most difficulty in organizing their notes and ideas, while only 25 percent found great difficulty in finding material, understanding their subjects, or in actually writing their papers. When given five choices as to what was the most profitable part of the assignment, 54 percent said it was trying to see another person as a prism of history. Organizing ideas and notes ( 22 percent) and learning to do research (14 percent) drew most of the other responses. Another 8 percent said the greatest profit came from learning to write effectively, but less than 2 percent pointed to learning to write correctly; this last response suggests that freshmen have an exaggerated view of their basic writing skills-many papers were returned covered with red corrections of spelling, punctuation and grammar errors.

Our project revealed certain weaknesses that should be faced frankly. Some students ended up with subjects that did not interest them, and hence they did not give their best effort. Often this was because they did not make a serious effort to pre-research subjects during the second week of the course and ended by signing up blindly for any name on the list. They waited too long before starting their research to recognize the problem and arrange with their TA for a new and better subject. Although our list contained the names of some 1700 subjects, with a book-length study in English on each at the University Library, we really did not have quite enough good subjects. ${ }^{3}$ In retrospect I think that a list of subjects should have twice the number of entries as students in the course. The British were over-represented on our list, while we did not have enough Spaniards for those students who wanted to use their skill at Spanish. We tried to offset this by including prominent figures from Latin America. Another problem was that our list included too many writers. Two series, Twayne's English Authors Series and Twayne's World Authors Series, are each represented in our library by several hundred slim volumes; many of these were the only work available on obscure writers, and their biographical sections were often thin. The biggest deficiency was that we did not have enough biographies of women. Half our students were women, many of whom preferred to work on women; they had to dig harder to find material than 
students working on males. Minority students were better served because Western Civilization courses inevitably tend to embrace Africa and Asia after 1870 so that our list of subjects included many recent African and Asian leaders.

The best papers usually dealt with figures of second rank importance, persons on whom our students could find several books and articles to digest. Students dealing with the giants of history were overwhelmed with too many sources and too complex a tale to tell in ten to fifteen pages. Students found that papers on some writers and most scientists, philosophers and theologians required more background than they possessed.

After implementing successfully the biographical sketch project in the second half of Western Civilization, I seriously considered doing the same for the first half of the course. I backed away from it after preparing more than 500 cards as a preliminary to making a list of subjects. At that point, it did not seem I would have enough good subjects, largely because hard biographical information is thin for most figures in Antiquity and the Middle Ages. Also, giving the same assignment in both halves of the course would seem repetitious. Moreover, a term paper in the first semester could not build so well on material taught in freshmen writing courses. ${ }^{4}$ Biographical sketches should fit nicely into survey courses of American history since most university libraries should have ample material. Likewise they can be used, mutatis mutandis, as a term paper assignment in many upper division history courses. ${ }^{5}$

\section{Notes}

1. I give lectures on Monday and Wednesday at 9:00 and 1:00 in a large lecture hall to classes ranging between 400 and 700 students. Once a week, on Thursday or Friday, students attend one of some fifty discussion sections run by the TAs. This old-fashioned arrangement, found in many universities for basic courses, has the obvious advantages of freeing up other professors for advanced courses and providing teaching assistantships for graduate students, but it carries the obvious disadvantages of size and impersonality, which are only partially offset by the small discussion sections. Two semesters of Western Civilization are required in two of the undergraduate colleges at Marquette University where I teach. In any given year about thirty small sections of Western Civilization are offered for students who are either in special programs (night school or the Honors Program) or who simply prefer smaller classes. Marquette attracts students somewhat above the national average but is not an elite school.

2. Barbara W. Tuchman, "Biography as a Prism of History" in her Selected Essays (New York: Knopf, 1981), 80-90. A recent discussion, with further bibliography, on how 
a history course can be built around biography is Glen Jeansonne's "Teaching a Course in Writing Biography." Perspectives: American Historical Association Newsletter, 26, 1 (Jan. 1988): 13-15.

3. The Marquette University Library has nearly one million volumes. Adjacent to our campus is the Milwaukee Public Library with more than one million volumes which our students can use. Students were asked to restrict their research to these two libraries. I provided material on our project to our librarians, and they gave valued help to many students. Students were asked not to use computerized search systems such as that for Dissertation Abstracts, both because these services can be very expensive and because they fail to teach students research skills.

4. I experimented for a semester with a short term paper based on J. Kelley Sowards's Makers of the WesternTradition: Portraits from History, Volume I (New York: St. Martin's Press, 1987). Sowards reprints material [usually one primary source and two recent interpretative essays plus an introduction] about fourteen major figures from Hammurabi to Louis XIV. The assignment required students to choose one of the fourteen individuals and asked them to evaluate the different interpretations, thereby preparing them for writing their own biographical sketches in the second semester of the Westem Civilization course. The assignment seemed less successful than the biographical sketches.

5. I would like to thank Laura Banas and Robert Lambeck for suggestions which improved this article. 